\section{Three polymorphisms at the D17S29 locus}

R.Ray, D.Rincon-Limas, R.A.Wright, S.N.Davis, J.R.Lupski ${ }^{1}$ and P.I.Patel Institute for Molecular Genetics and ${ }^{1}$ Department of Pediatrics, Baylor College of Medicine, Houston, TX 77030, USA

Source/Description: A 4 kb EcoRI fragment from cosmid YNM67 was subcloned into the EcoRI site of pTZ19R.

Polymorphism: TaqI identifies a two allele polymorphism (A1: $3.4 \mathrm{~kb}, \mathrm{~A} 2: 2 \mathrm{~kb}+1.3 \mathrm{~kb}$ ) with constant bands of $0.86 \mathrm{~kb}$ and $1.45 \mathrm{~kb}$. BglII identifies a two allele polymorphism (B1: $8.1 \mathrm{~kb}$, B2: $6.7 \mathrm{~kb}$ ) with no constant bands. BamHI identifies a two allele polymorphism $(\mathrm{C} 1: 5.1 \mathrm{~kb}, \mathrm{C} 2: 3.9 \mathrm{~kb})$ with no constant bands.

Frequency: (estimated from the designated number $(\mathrm{N})$ of unrelated Caucasians)
TaqI $(\mathbf{N}=21)$
$\operatorname{BglII}(\mathrm{N}=19)$
A1: 0.45
B1: 0.21
$\operatorname{BamHI}(\mathrm{N}=18)$
A2: 0.55
B2: 0.79
C1: 0.78
C2: 0.22

Not Polymorphic For: RsaI, PvuII, Hinfl, or HindIII in a panel of 8 unrelated individuals. EcoRI identifies an apparent RFLP which is artifactual since it does not exhibit Mendelian inheritance.

Chromosomal Localization: pYNM67-R5 was assigned to chromosome $17 \mathrm{p} 11.2$ using a previously published chromosome 17-somatic cell hybrid panel $(1,2)$. This localization is based on the lack of hybridization to hybrid DH110-D1 retaining a $\operatorname{del}(17)(\mathrm{p} 11.2 \mathrm{p} 11.2)$.

Mendelian Inheritance: Codominant segregation of these RFLPs has been observed in one large three-generation French-Acadian kindred (34 individuals).

Probe Availability: Contact ATCC.

Other Comments: Preassociation with human placental DNA is required prior to hybridization at normal stringency $\left(65^{\circ} \mathrm{C}, 1\right.$ $\mathrm{M} \mathrm{Na}^{+}$) (2). TaqI and RsaI RFLPs were previously detected by a 1.6 kb PstI fragment from the cosmid YNM67 (Nakamura,Y., personal communication) but this probe often yielded high lane background.

Acknowledgements: We thank Drs. Yusuke Nakamura and Ray White for providing cYNM67. This work was supported by an MDA Task Force grant, by the Baylor Mental Retardation Research Center (HD24064-02), NIH grant R01 NS27042 and an Advanced Technology Program grant from the state of Texas to J.R.L and P.I.P.

References: 1)van Tuinen,P. et al. (1988) Am. J. Hum. Genet. 43, 587-596. 2) Patel,P.I. et al. (1990) Am. J. Hum. Genet. 46, $801-809$.

\section{Tetranucleotide repeat polymorphism in the LPL gene}

Giovanni Zuliani and Helen H.Hobbs

Department of Molecular Genetics, University of

Texas Southwestern Medical Center, 5323 Harry Hines Boulevard, Dallas, TX 75235, USA

Source/Description: A polymorphism (TTTA) $n$ in intron 6 of the lipoprotein lipase gene at the $3^{\prime}$ end of an Alu sequence (1). The polymerase chain reaction (PCR) was used to selectively amplify the sequence from genomic DNA, using two oligonucleotides flanking the repeat. The expected size of the fragment is $127 \mathrm{bp}$.

Primer Sequence:

GZ-14 = ATCTGACCAAGGATAGTGGGATATA GZ-15 = CCTGGGTAACTGAGCGAGACTGTGTC

Frequency: estimated in 20 unrelated Caucasian American individuals:

$\begin{array}{lll}\text { Allele (nt) } & \begin{array}{l}\text { Number of } \\ \text { (TTTA) Repeats }\end{array} & \text { Frequency } \\ 131 & 12 & 0.08 \\ 127 & 11 & 0.46 \\ 123 & 10 & 0.46\end{array}$

Heterozygosity index is $54 \%$ and the alleles are in HardyWeinberg equilibrium.

Mendelian Inheritance: Co-dominant segregation was observed in one family with 12 informative meiosis.

Chromosomal Localization: LPL gene has been assigned to chromosome 8p22 (2).

Other Comments: The PCR was performed as previously described (3) using end-labeled oligo GZ-14 and unlabeled oligo GZ-15 with the following modifications: 1) denaturation at $96^{\circ} \mathrm{C}$ for $1 \mathrm{~min}$., 2) annealing and extension at $68^{\circ} \mathrm{C}$ for $3 \mathrm{~min}$., and 3 ) the number of cycles was 25 . PCR product was fractionated on $8 \%$ denaturing polyacrylamide gel. The size of allele was determined by comparison with end-labeled MspI digested pBR322 DNA (Figure).

References: 1) Oka,K. et al. (1989) Nucl. Acids Res. 17, 6752. 2) Heinzman,C. et al. (1987) Nucl. Acids Res. 15, 6763. 3) Saiki,R.K. et al. (1988) Science 230, 487-491.

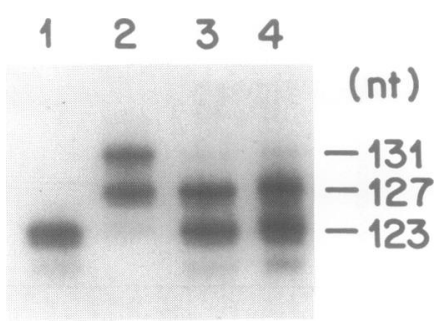

